\title{
Europejska klasyfikacja NUTS i jej znaczenie dla województwa mazowieckiego
}

\section{Konrad Wojnarowski}

\section{STRESZCZENIE}

Celem artykułu jest przedstawienie europejskiej klasyfikacji NUTS oraz jej znaczenia dla województwa mazowieckiego. Wobec nowego podziału statystycznego Mazowsze stoi przed wyzwaniem zwiększenia trwałości polityki rozwoju przy założeniu „spójności terytorialnej, rozumianej jako zmniejszenie dysproporcji rozwoju w województwie mazowieckim oraz wzrost znaczenia Obszaru Metropolitalnego Warszawy w Europie” [Strategia... 2013, s. 6].

Słowa kluczowe: rozwój regionalny, NUTS, województwo mazowieckie, polityka regionalna

\section{Wstęp}

Podobnie, jak podstawowym zadaniem samorządu województwa jest kreowanie rozwoju regionalnego, tak ogólną zasadą polityki regionalnej Unii jest wspieranie przede wszystkim regionów słabiej rozwiniętych, których PKB w przeliczeniu na mieszkańca jest niższe niż 75\% średniej dla Unii Europejskiej. Województwo mazowieckie przekroczyło ten poziom już w 2004 r. Natomiast w latach 2008-2014 uzyskało wzrost PKB na mieszkańca o około 25 p.p., tj. z poziomu 85\% średniej Unii Europejskiej do poziomu 109\% średniej UE. Mimo, że Mazowieckie znalazło się na piątym miejscu najszybciej rozwijających się makroregionów ${ }^{1}$ Unii, jednak największym problemem pozostaje nadal jego duże zróżnicowanie wewnętrzne. Dlatego też nadrzędnym celem określonym w strategii województwa mazowieckiego jest „spójność terytorialna, rozumiana jako zmniejszenie dysproporcji rozwoju w województwie mazowieckim oraz wzrost znaczenia Obszaru Metropolitalnego Warszawy w Europie" [Strategia... 2013, s. 6]. Duże znaczenie w tym zakresie ma nowy podział statystyczny, zgodnie z którym, województwo mazowieckie od stycznia 2018 r. jest formalnie makroregionem NUTS 1, składającym się z dwóch regionów NUTS 2, mianowicie regionu warszawskiego stołecznego, który obejmuje Warszawę i dziewięć powiatów, a także regionu mazowieckiego regionalnego - obejmującego pozostałą część województwa.

\footnotetext{
1 Regionem jest nazywana jednostka NUTS 2. Od 1 stycznia 2018 r. województwo mazowieckie jest podzielone statystycznie na dwa NUTS 2.
} 


\section{Przestrzeń Mazowsza}

Województwo mazowieckie jest największym województwem w kraju zarówno pod względem zajmowanego obszaru - 35, 6 tys. $\mathrm{km}^{2}$ (11,4\% powierzchni Polski), jak i liczby ludności - 5,35 mln osób (ponad 14 \% ludności Polski). Strukturę terytorialną województwa tworzą 42 powiaty w tym 5 miast na prawach powiatu oraz 314 gmin, w tym 35 gmin miejskich, 52 gminy miejsko-wiejskie, 227 gmin wiejskich. Do głównych, a jednocześnie fundamentalnych cech województwa, które mają wpływ na dalszy jego rozwój, należy potencjał rozwojowy, wynikający m.in. z uwarunkowań przestrzennych. Województwo mazowieckie charakteryzuje się wysokim tempem wzrostu gospodarczego oraz najwyższym wśród województw udziałem w generowaniu PKB kraju. Najszybciej niweluje różnice w rozwoju, w stosunku do rozwiniętych krajów Unii Europejskiej. Niewątpliwie motorem rozwoju województwa jest metropolia warszawska, stanowiąca ponadregionalny europejski ośrodek wzrostu, w którym koncentrują się funkcje krajowego centrum społeczno-politycznego. Metropolia ogniskuje wzrost i rozwój działalności gospodarczej, jest głównym ośrodkiem edukacji i kultury. Inwestorzy koncentrują działalność przede wszystkim w Warszawie i jej otoczeniu, wykorzystując rozwój społecznogospodarczy metropolii oraz, korzyści płynące $\mathrm{z}$ położenia w stolicy kraju i regionu lub jej bezpośrednim sąsiedztwie, w tym efekt skali. Położenie Mazowsza na przecięciu europejskich korytarzy transportowych oraz gęsta sieć dróg zapewniają powiązania z policentryczną siecią krajowych ośrodków wzrostu, a także z regionami i ośrodkami europejskimi. „Uwarunkowania zewnętrzne, dotyczące kierunków rozwoju przestrzennego województwa mazowieckiego, wynikają z dokumentów krajowych, określających model rozwoju przestrzennego i społeczno-gospodarczego Polski w perspektywie do 2030 r.: Koncepcji przestrzennego zagospodarowania kraju 2030 oraz Strategii na rzecz odpowiedzialnego rozwoju do roku 2020 (z perspektywą do 2030 r.)" [Plan... 2018, s. 13-14].

Kluczową cechą przestrzeni województwa jest także jej zróżnicowanie. Szczególnie wyraźny jest dysonans wewnętrzny, w którym wyróżnić należy przede wszystkim dwie przestrzenie, mianowicie metropolię warszawska, zajmującą 1\% powierzchni województwa, na której mieszka 1/3 mieszkańców, wytwarzająca około 61\% PKB i tereny rolne-obejmujące $2 / 3$ powierzchni województwa, zamieszkane przez $1 / 3$ populacji generującą $3 \%$ PKB. Taka struktura przestrzeni prowadzi do dwuczłonowości rozwoju oraz wzmacnia układ rdzeńperyferia. Zróżnicowanie wyraża się również w polaryzacji, będącej w znacznej mierze skutkiem wspomnianej wyżej dychotomii, przejawiającej się w wielu aspektach, m.in. jako polaryzacja gospodarcza. Umacnia ją pozycja województwa mazowieckiego - makroregionu generującego największy PKB, głównie dzięki dynamicznie rozwijającej się Warszawie i jej obszarowi metropolitalnemu [Plan... 2014, s. 13]. Według najnowszych danych, opublikowanych przez Eurostat 26 lutego 2019 r., wartość PKB per capita dla makroregionu województwo mazowieckie wynosi $112 \%$ średniej unijnej. Jednak region warszawski stołeczny to $152 \%$ średniej, przy zaledwie 59\% regionu mazowieckiego regionalnego (na podstawie danych z 2017 r.) [https://ec.europa.eu]. 
Ze względu na duże zróżnicowanie funkcjonalno-przestrzenne rozwoju województwa mazowieckiego, konieczne jest wprowadzenie narzędzi zmniejszających te dysproporcje.

Osiągnięcie spójności terytorialnej, będzie możliwe m.in. „poprzez przyspieszenie wzrostu gospodarczego, generowanego przez rozwój produkcji i przemysłu ukierunkowanego na eksport, szczególnie w branży średniozaawansowanych i zaawansowanych technologii" [Strategia... 2013, s. 1].

Zróżnicowanie wewnętrzne Mazowsza oznacza, że występują tu wielorakie potencjały rozwojowe. Strategia wskazuje cztery tzw. obszary strategicznej interwencji (OSI): płockociechanowski, ostrołęcko-siedlecki, radomski oraz obszar strategicznej interwencji - biegun wzrostu, którym jest Obszar Metropolitalny Warszawy. Te cztery charakterystyczne jednostki wyróżniają się szczególnymi cechami, np. obszar płocko-ciechanowski składa się z dwóch podregionów, spośród których podregion płocki dostarcza 2,5\% krajowej wartości dodanej brutto w rolnictwie, podregion ciechanowski zaś 3,6\%, a charakteryzuje je specjalizacja głównie mięsna oraz częściowo owocowo-warzywna. Odnosząc się do Obszaru Metropolitalnego Warszawy, należy wymienić rdzeń, tj. m.st. Warszawę z bardzo mocno rozwiniętymi usługami, część wschodnią z relatywnie wysoko rozwiniętą działalnością przemysłową i budowlaną oraz część zachodnią z rozwiniętą działalnością handlowousługową i budowlaną [Swianiewicz, Dąbrowska 2018, s. 63]. Mazowsze (województwo mazowieckie) jest makroregionem dwoistym, o bardzo dobrze rozwiniętym rdzeniu skupiającym się wokół Warszawy, ale ze znacznie słabszymi gospodarczo obszarami we wspomnianych wcześniej podregionach radomskim, ostrołęckim, siedleckim czy ciechanowskim. Uboższe części województwa - w myśl logiki kierującej polityką regionalną Unii Europejskiej - zasługują na wsparcie w nie mniejszym stopniu niż województwa, dla których w 2007 r. stworzono specjalny Program Operacyjny Rozwój Polski Wschodniej. Mazowsze nie bierze jednak w nim udziału ze względu na wysokie średnie wskaźniki zamożności. W związku z tym samorząd województwa od dawna zabiegał o statystyczny podział Mazowsza na dwa regiony NUTS 2: Warszawę i otaczające ją powiaty oraz pozostałą część województwa, z których ten drugi mógłby korzystać z wyższych dotacji pochodzących z programów unijnych [Swianiewicz, Dąbrowska 2018, s. 76].

\section{Pojęcie NUTS}

NUTS to Klasyfikacja Jednostek Terytorialnych do Celów Statystycznych (Nomenclature of Territorial Units for Statistics). Jest to standard geograficzny służący do statystycznego podziału państw członkowskich Unii Europejskiej na trzy poziomy regionalne o określonych klasach liczby ludności. Ustanowiono ją w celu „zbierania, opracowania i rozpowszechniania na obszarze Unii Europejskiej porównywalnych danych regionalnych (np. z zakresu rachunków regionalnych, demografii, rynku pracy, społeczeństwa informacyjnego)" [stat.gov.pl].Zadaniem klasyfikacji NUTS jest również kształtowanie polityki regionalnej krajów Unii Europejskiej. Zjej pomocą przeprowadzane są analizy społeczno-gospodarcze regionów. Wprowadzona została rozporządzeniem Parlamentu Europejskiego i Rady z dnia 26 maja 2003 r. a weszła w życie 
11 lipca 2003 r. [Rozporzadzenie... 2003]. Głównym celem klasyfikacji NUTS jest rozwiązanie problemu różnorodności podziałów administracyjnych krajów członkowskich UE.

Pierwsze uregulowanie nawiązujące do szeroko pojętego podziału terytorialnego, także NUTS w polskim porządku prawnym, zostało uchwalone w ustawie o statystyce publicznej. Na podstawie art. 40 ust. 2 ustawy z dnia 29 czerwca 1995 r. o statystyce publicznej [Ustawa... 1995] wydano przepisy dotyczące podziału terytorialnego. Zgodnie z wyżej wymienionym artykułem, Prezes Głównego Urzędu Statystycznego, w porozumieniu z właściwymi naczelnymi organami administracji państwowej, opracowuje podstawowe do określenia przebiegu i opisu procesów gospodarczych i społecznych standardowe klasyfikacje i nomenklatury, wzajemne relacje między nimi oraz ich interpretacje. Klasyfikacje i nomenklatury wprowadza Rada Ministrów w drodze rozporządzenia. "Stosuje się je w statystyce, ewidencji i dokumentacji oraz rachunkowości, a także w urzędowych rejestrach i systemach informacyjnych administracji publicznej" [Ustawa... 1995]. Jak twierdzi H. Izdebski, jest to istotny przepis dotyczący podziału terytorialnego w sposób oczywisty niezgodny z Konstytucją. Wskazuje natomiast, że rozporządzenie nr 1059/2003 Parlamentu Europejskiego i Rady [Rozporzadzenie... 2003] wprowadziło zasady dotyczące dokonywania przez właściwe organy państw członkowskich zmian w podziale na jednostki NUTS, zmierzając do względnego usztywnienia przyjętego podziału [Izdebski 2014, s. 225227]. Ponadto należy zauważyć, że od 1 stycznia 2018 r. nie obowiązuje już - wydane na blankietowej podstawie art. 40 ust. 2 ustawy o statystyce publicznej, a do tego dublujące, czego być nie powinno, rozporządzenie UE o NUTS - rozporządzenie Rady Ministrów z 14 listopada 2007 r. w sprawie wprowadzenia NTS. Mamy wobec tego obecnie stan prawny klarowny z punktu widzenia zarówno prawa konstytucyjnego, jak i prawa UE.

Pojęcie NUTS zostało użyte i funkcjonowało w przestrzeni europejskiej już nieco wcześniej, kiedy Biuro Statystyczne Wspólnoty Europejskiej opracowało podział na terytorialne jednostki statystyczne obszaru EWG. Podział ten stał się podstawą wyznaczenia regionów objętych pomocą Funduszy Strukturalnych. Biuro dopuszczało różne systemy wydzielania terytoriów: 1) regiony normatywne (granice administracyjne); 2) regiony analityczne: a) funkcjonalne (połączenie uzupełniających się stref), b) homogeniczne (połączenie stref o podobnych charakterystykach). Z powodów praktycznych, szczególnie łatwości pozyskiwania danych, jednostki terytorialne NUTS opierają się głównie na podziale formalnym obowiązującym w państwach członkowskich. Lista NUTS ma charakter ogólny nie wyróżnia się żadnych regionów specjalnych. Początkowo obowiązywał trójpoziomowy podział: NUTS 1, NUTS 2, NUTS 3, później dodano kolejne dwa poziomy. Każde z państw podzielone jest na skończoną liczbę regionów ze wszystkich poziomów, a każdy poziom ma skończoną liczbę jednostek niższego rzędu. Poziomem, dla którego prowadzi się wszystkie analizy i do którego w konsekwencji dociera polityka regionalna, jest przede wszystkim NUTS 2, ale są też przypadki adresowania pomocy do regionów wyznaczonych przez inne poziomy [Klima 2005, s. 25].

W dniu 29 listopada 2016 r. w Dzienniku Urzędowym Unii Europejskiej zostało opublikowane Rozporządzenie Komisji (UE) 2016/2066 z dnia 21 listopada 2016 r. zmieniające 
załączniki do rozporządzenia (WE) nr 1059/2003 Parlamentu Europejskiego i Rady w sprawie ustalenia wspólnej klasyfikacji Jednostek Terytorialnych do Celów Statystycznych (NUTS). Rozporządzenie to jest rezultatem rundy rewizji wspólnej Klasyfikacji Jednostek Terytorialnych do Celów Statystycznych (NUTS), tzw. rewizja NUTS 2016. W ramach tej rundy rewizji dokonano modyfikacji w podziałach na jednostki statystyczne 9 państw członkowskich UE - zmiany te polegają bądź na zmianie liczby tych jednostek, bądź na samej zmianie granic jednostek, bez zmiany ich liczby [stat.gov.pl].

Na poziomie NUTS 2 województwo mazowieckie, które stanowiło do tej pory jedną jednostkę statystyczną tego poziomu, podzielono na dwie jednostki statystyczne, a mianowicie region Warszawski stołeczny oraz Mazowiecki regionalny. Pierwszy obejmuje Warszawę i sąsiednie powiaty: legionowski, miński, nowodworski, otwocki, wołomiński, grodziski, piaseczyński, pruszkowski i warszawski zachodni, drugi natomiast pozostałą część makroregionu. Liczba poziomów NUTS 2 wzrosła z 16 do 17. Tym samym zmianie uległa nazwa poziomu na „regiony” (dotychczasowa nazwa to „województwa”). „Konsekwencją zmiany podziału Polski na jednostki NUTS 2 jest modyfikacja podziałów na pozostałych poziomach. Na poziomie NUTS 1 zmiana polega na utworzeniu nowej jednostki obejmującej samo województwo mazowieckie: Makroregionu Województwo Mazowieckie. Na poziomie NUTS3 powiat garwoliński przyłączony zostaje do podregionu siedleckiego (dotychczas w podregionie warszawskim wschodnim), powiat nowodworski do podregionu warszawskiego zachodniego (dotychczas w podregionie warszawskim wschodnim). Utworzony zostaje natomiast nowy podregion żyrardowski obejmujący powiaty grójecki, sochaczewski i żyrardowski (dotychczas wszystkie w podregionie warszawskim zachodnim)" [stat.gov.pl].

Zmiany, które zostały wprowadzone rundą rewizji NUTS 2016 mają swoje odniesienie w stosunku do ośmiu innych państw Unii Europejskiej. W jednym na poziomie NUTS 1 , w czterech na poziomie NUTS 2 i w czterech na poziomie NUTS 3. W Finlandii zmieniono granice dwóch jednostek NUTS 3. We Francji zwiększono liczbę jednostek poziomu NUTS 1 z 9 do 14. Zmiana została dokonana ze względu na nowy podział administracyjny kraju. Poziom administracyjny uzyskał status poziomu NUTS 1, natomiast przestał być traktowany $\mathrm{w}$ ten sposób poziom NUTS 2. W Holandii zmieniono granice siedmiu jednostek NUTS 3 . W Irlandii zwiększono liczbę jednostek NUTS 2 z dwóch do trzech, poprzez utworzenie jednostki obejmującej stolicę państwa wraz z okalającymi terenami. Na Litwie natomiast utworzono jednostkę, obejmującą wyłącznie obszar administracyjny, w której znajduje się stolica kraju, przez co zwiększyła się liczba jednostek NUTS 2 z jednej do dwóch.W Niemczech zmiana granic dotknęła dwóch jednostek NUTS 3, a dwie jednostki NUTS 3 połączono. Na Węgrzech zwiększono liczbę jednostek NUTS 2 z siedmiu do ośmiu poprzez utworzenie jednostki obejmującej stolicę kraju w jej granicach administracyjnych. W Wielkiej Brytanii natomiast zwiększona została liczba jednostek NUTS 2 z 40 do 41. Utworzono dodatkową jednostkę na obszarze Szkocji oraz zwiększono liczbę jednostek NUTS 3 ze 173 do 179. Na obszarze Irlandii Północnej zmiana dostosowała podział statystyczny do nowego podziału administracyjnego [stat.gov.pl]. 


\section{EUROPEJSKA KLASYFIKACJA NUTS I JEJ ZNACZENIE DLA WOJEWÓDZTWA ... \\ Konrad Wojnarowski}

Jako ciekawostkę należy nadmienić, iż największe powierzchniowo NUTS 2 zlokalizowane są w Szwecji i Finlandii. Największym NUTS 2, pod względem kryterium liczby ludności, jest region Île-de-France we Francji, składający się z ośmiu departamentów będących oddzielnymi jednostkami administracyjnymi, który skupia ok. 18\% mieszkańców kraju (ok. $12 \mathrm{mln}$ ) oraz Lombardia we Włoszech (ok. 9,5 mln mieszkańców), składająca się z 12 prowincji jako samodzielnych jednostek administracyjnych. Najmniejszych 15 regionów NUTS 2 liczy poniżej 300 tys. mieszkańców - są to w szczególności regiony peryferyjne i wyspy (Wyspy Alandzkie, Azory, Gujana Francuska, La Rioja, Burgenland) [Machelski 2015, s. 170].

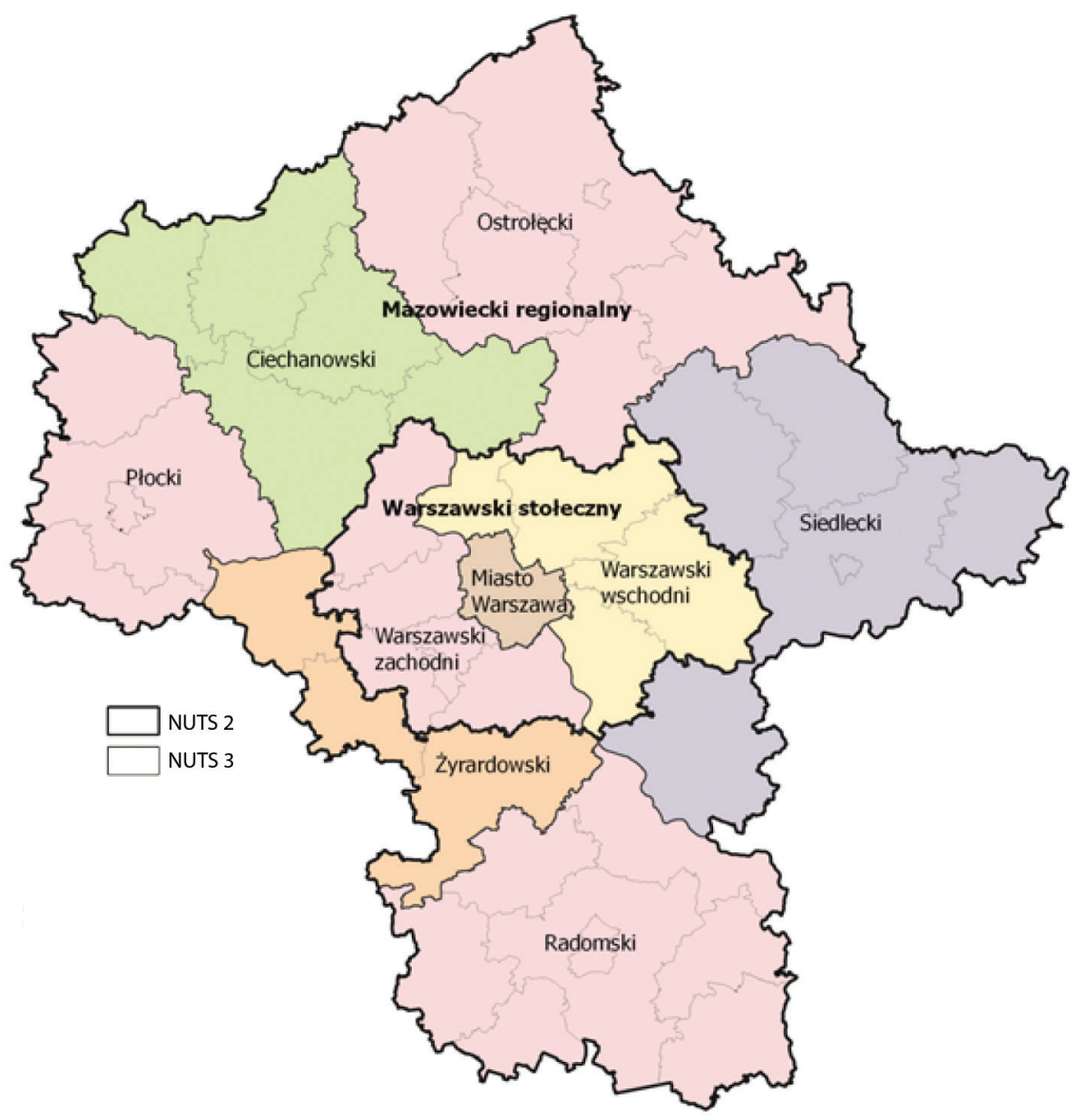

Ryc. 1. Podział województwa mazowieckiego na jednostki NUTS obowiązujący od 1 stycznia 2018 r. Źródło: Mazowieckie Biuro Planowania Regionalnego w Warszawie 
Jednostki NUTS, jako subeuropejskie jednostki terytorialne, wciąż stają się nośnikiem polityki wspólnotowej, silnie powiązanej $\mathrm{z}$ terytorialnie zorientowanymi strategiami krajowymi i terytorialnymi. Jej beneficjentami są jednostki regionalne i lokalne. Z punktu widzenia skuteczności realizacji polityki regionalnej niewątpliwie idealnym rozwiązaniem jest kompatybilność krajowych i unijnych struktur regionalnych [Machelski 2015, s. 142].

\section{Kontekst Mazowsza}

Podział na „nowe” NUTS 2 pozwoli dostosować wysokość i rodzaj wsparcia z funduszy unijnych do poszczególnych regionów lub podregionów/subregionów województwa. Zasadnicze pytanie brzmi: czy nastąpi to już w perspektywie 2021-2027? Niezwykle istotne dla przyszłości regionu będzie to, które dane i wskaźniki zostaną wzięte pod uwagę przy tworzeniu programów europejskich.

Mimo wskazanej wyżej niepewności i braku - na obecny moment - wiążących decyzji, podział statystyczny zapewni bardziej transparentny obraz sytuacji społeczno-gospodarczej na Mazowszu, uwzględniając znaczące dysproporcje w poziomie PKB pomiędzy poszczególnymi częściami województwa. Otoczenie stolicy cechuje się poziomem PKB na 1 mieszkańca zdecydowanie powyżej średniej unijnej, podczas gdy pozostała część województwa plasuje się wyraźnie poniżej progu 75\% średniej dla Unii Europejskiej. Wprowadzenie nowego podziału statystycznego zdecydowanie ułatwia zróżnicowanie interwencji po 2020 r. Daje możliwość konstrukcji wyższego stopnia dofinansowania $\mathrm{w}$ ramach pomocy skierowanej do obszarów problemowych wyznaczonych w Strategii rozwoju województwa mazowieckiego do 2030 roku. Ekspansywny rozwój województwa mazowieckiego i jego rozbieżność wewnętrzna spowodowały bowiem, że uśrednione mierniki ogólnowojewódzkie nie ilustrowały rzeczywistej sytuacji w odniesieniu do terenów pozametropolitalnych. Z badań Europejskiego Urzędu Statystycznego wynika, że w latach 2008-2014 województwo mazowieckie uzyskało najwyższy wzrost PKB na 1 mieszkańca, o około 25 p.p., z poziomu 85\% średniej UE do 109\%. Mazowieckie uzyskało wyższy poziom rozwoju od średniej, wyprzedzając 275 regionów i znalazło się w pierwszej piątce najszybciej rozwijających się (makro)regionów Unii [Machelski 2015].

Podział na dwa NUTS 2 umożliwi w kolejnej perspektywie bardziej precyzyjne podejście do planowania rozwoju obszarów oraz znacznie lepsze dopasowanie pomocy publicznej do realnych potrzeb. Jak słusznie zauważa P. Swianiewicz, wydzielenie statystyczne zachowuje dochody Mazowsza i pozwala uwzględnić jego zróżnicowanie gospodarcze. Ponadto daje szansę efektywnego wykorzystania środków europejskich w przyszłej perspektywie finansowej, tzn. po 2020 r. Nie generuje dodatkowych kosztów, a umożliwia uzyskanie właściwego wsparcia dla subregionów siedleckiego, ostrołęckiego, radomskiego, płockiego i ciechanowskiego [Swianiewicz 2016].

Wydaje się oczywiste, że wobec takich wyzwań dla Mazowsza jak polaryzacja rozwoju województwa, nowy podział statystyczny, nowa perspektywa finansowa czy zmniejszenie dofinansowania z UE, jako obszary zastosowań, duże znaczenie w rozwoju 
całego makroregionu (obu regionów NUTS 2) będą miały takie instrumenty jak np. ZIT i RIT oraz instrumenty zwrotne, a także obszary strategicznej interwencji. Zintegrowane inwestycje terytorialne, jako szczególny instrument realizacji programów operacyjnych dla obszarów metropolitalnych, oraz regionalne inwestycje terytorialne dla obszarów pozametropolitalnych, powinny być uwzględnione $\mathrm{w}$ szczególny sposób $\mathrm{w}$ trakcie przygotowań instrumentów wdrażania polityki w odniesieniu do rozwoju i potencjału NUTS 2 warszawskiego stołecznego i mazowieckiego regionalnego.

Polska jest jednym z niewielu krajów, w którym w istotny sposób zdecentralizowano gospodarowanie funduszami unijnymi. Decentralizacja jest na pewno jednym $z$ kluczowych czynników, dzięki którym zarządzanie funduszami unijnymi w Polsce jest lepsze niż w większości innych krajów w Europie Środkowo-Wschodniej [Swianiewicz 2016]. Należy przypomnieć, że decentralizacja jest jedną z podstawowych konstytucyjnych zasad samorządu terytorialnego. Zasada ta została wyrażona w art. 15 ust. 1 Konstytucji RP. Stanowi on, iż ustrój terytorialny Rzeczypospolitej Polskiej zapewnia decentralizację władzy publicznej [www.sejm.gov.pl].

\section{Podsumowanie}

Po 1 stycznia 2018 r. klasyfikacja NUTS nabrała szczególnego znaczenia dla polityki rozwoju województwa mazowieckiego. Konieczne wydaje się zaproponowanie nowych oraz dostosowanie istniejących instrumentów, a także kierunków rozwoju na obszarze makroregionu. Zmiana klasyfikacji jednostek terytorialnych do celów statystycznych poprzez wyłonienie dwóch jednostek NUTS 2, powoduje konieczność zwiększenia trwałości polityki rozwoju regionalnego związanej z nową perspektywą finansową UE.

\section{Literatura}

Izdebski H., 2014, Samorząd terytorialny. Podstawy ustroju i działalności, LexisNexis Polska, Warszawa.

Klima E., 2005, Polityka regionalna $i$ wspótpraca transgraniczna w świetle dziatań instytucji europejskich, Acta Universitatis Lodziensis. Folia Geographica Socio-Oeconomica, 6, s. 23-41.

Machelski Z., 2015, Struktury terytorialne państwa, Wydawnictwo Sejmowe, Warszawa.

Plan zagospodarowania przestrzennego województwa mazowieckiego, 2014, MBPR, Warszawa.

Plan zagospodarowania przestrzennego województwa mazowieckiego, 2018, MBPR, Warszawa.

Rozporządzenie (WE) nr 1059/2003 Parlamentu Europejskiego i Rady z dnia 26 maja 2003 r. w sprawie ustalenia wspólnej klasyfikacji Jednostek Terytorialnych do Celów Statystycznych (NUTS) (Dz. Urz. UE L 154 z 21.06.2003). 
Rozporządzenie (WE) nr 1888/2005 Parlamentu Europejskiego i Rady z dnia 26 października 2005 r. zmieniające rozporządzenie (WE) nr 1059/2003 w sprawie ustalenia wspólnej klasyfikacji Jednostek Terytorialnych do Celów Statystycznych (NUTS) z powodu przystąpienia Czech, Estonii, Cypru, Łotwy, Litwy, Węgier, Malty, Polski, Słowenii i Słowacji do Unii Europejskiej (Dz. Urz. UE L 309 z 25.11.2005).

Strategia rozwoju województwa mazowieckiego do 2030 roku. Innowacyjne Mazowsze, 2013, MBPR, Warszawa.

Swianiewicz P., 2016, Podział województwa mazowieckiego - błąd społeczny i ekonomiczny? Materiały pokonferencyjne, Urząd Marszałkowski Województwa Mazowieckiego, Warszawa.

Swianiewicz P., Dąbrowska A. (red.), 2018, Mazowsze. Ekonomia i Gospodarka, WGiSR UW, Warszawa.

Ustawa z dnia 29 czerwca 1995 roku o statystyce publicznej (Dz.U. z 1995 r., nr 88, poz. 439).

\section{Strony internetowe}

http://prawo.sejm.gov.pl/isap.nsf/DocDetails.xsp?id=WDU19950880439

http://stat.gov.pl/statystyka-regionalna/jednostki-terytorialne/klasyfikacja-nuts/rewizja-klasyfikacji-nuts-2016/

http://www.sejm.gov.pl/prawo/konst/polski/kon1.htm

https://ec.europa.eu/eurostat/documents/2995521/9618249/1-26022019-AP-EN.pdf/f765d183c3d2-4e2f-9256-cc6665909c80 


\section{EUROPEJSKA KLASYFIKACJA NUTS I JEJ ZNACZENIE DLA WOJEWÓDZTWA ... \\ Konrad Wojnarowski}

\section{European NUTS classification and its significance for the Mazowieckie Voivodship}

\section{ABSTRACT}

The aim of the article is to present the European NUTS classification and its importance for the Mazowieckie Voivodship. In view of the new statistical division, Mazovia faces the challenge of increasing the sustainability of development policy with the assumption of territorial cohesion, understood as reducing development disparities in the Mazowieckie Voivodship and increasing the importance of the Warsaw Metropolitan Area in Europe.

Keywords: regional development, NUTS, Mazowieckie Voivodship, regional policy

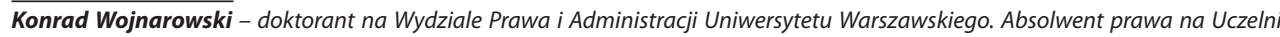
Łazarskiego oraz stosunków międzynarodowych na Uniwersytecie Kardynała Stefana Wyszyńskiego. Jego obszar badawczy obejmuje m. in. zakres prawa samorzq̨du terytorialnego oraz szeroko rozumianej polityki regionalnej.

Konrad Wojnarowski, PhD student at the Faculty of Law and Administration at the University of Warsaw. A law graduateat the Lazarski University and international relations at the Cardinal Stefan Wyszyński University. His research are includes, among others scope of local self-government law and broadly understood regional policy. 